\title{
PENATALAKSANAAN NYERI SENDI PADA LANSIA \\ MENGGUNAKAN TEKNIK HIPNOTERAPI \\ DI PANTI SOSIAL TRESNA WERDA BUDI LUHUR JAMBI
}

\author{
Abbasiah, Gusti Lestari Handayani, Sovia \\ Jurusan Keperawatan Poltekkes Kemenkes Jambi, Indonesia \\ * Korespondensi penulis: saza_abay@yahoo.co.id
}

\begin{abstract}
ABSTRAK
Latar belakang: Nyeri sendi merupakan penyakit yang banyak diderita pada lansia, sehingga perlu mendapatkan perhatian melalui penatalaksanaan manajemen nyeri. Salah satu terapi komplementer yang telah dikembangkan dan dapat menjadi alternatif pengurangan penggunaan terapi farmakologi dengan pengelolaan alam bawah sadar yaitu hipnoterapi. Penelitian ini bertujuan untuk mengetahui pengaruh hipnoterapi terhadap skala nyeri sendi pada lansia.

Metode: Desain penelitian adalah quasi eksperimen dengan rancangan one group pre test- post test. Penelitian dilakukan pada bulan Agustus sampai September 2018, dengan jumlah sampel 20 orang lansia yang menderita nyeri sendi. Sampel dipilih secara purposive sampling. Pengumpulan data dilakukan menggunakan Verbal Descriptor Scale. Analisis data menggunakan uji Wilcoxon Signed Ranks Test untuk membandingkan perbedaan rerata nyeri sebelum dan sesudah intervensi.

Hasil: Hasil penelitian menunjukkan ada perbedaan rerata nyeri pada lansia sebelum dan sesudah intervensi hipnoterapi (nilai p $0,000<\alpha 0,05 ;$ CI $4,844-5,956$ ).

Kesimpulan: Berdasarkan hasil penelitian ini dapat disimpulkan bahwa ada pengaruh hipnoterapi terhadap penurunan nyeri sendi pada lansia.
\end{abstract}

Kata kunci: lansia; nyeri sendi; hipnoterapi; verbal descriptor scale

\section{MANAGEMENT OF JOINT PAIN IN THE ELDERLY USING HYPNOTHERAPY IN PANTI SOSIAL TRESNA WERDA BUDI LUHUR JAMBI}

\section{ABSTRACT}

Background: Joint pain is a disease that is much suffered in the elderly, so it is necessary to get attention through pain management treatment. One of the complementary therapies that have been developed and can be an alternative reduction of the use of pharmacological therapy with the management of the unconscious is hypnotherapy. This study aims to determine the influence of hypnotherapy on the joint pain scale in the elderly.

Method: This research was a quasi-experiment with one group pre-test-post test design. The study was conducted from August to September 2018, a total of 20 elderly people suffering from joint pain were recruited for the research using purposive sampling method. Data was collected using Verbal Descriptor Scale followed by statistic analisis using the Wilcoxon Signed Ranks Test to compared the average difference in pain before and after the intervention.

Results: The results showed no difference in the average pain in the elderly before and after the hypnotherapy intervention ( $p 0.000<\alpha 0.05 ;$ CI $4.844-5.956)$.

Conclusion: Based on the results of the study it can be concluded that there was a hypnotherapy influence on the decrease in joint pain in the elderly.

Keywords: elderly; joint pain; hypnotherapy; verbal descriptor scale 


\section{PENDAHULUAN}

Nyeri sendi merupakan penyakit yang banyak diderita pada lansia. Efek nyeri dapat menyebabkan penurunan aktifitas, isolasi sosial, gangguan, tidur,kecemasan dan depresi. ${ }^{1.2}$

Manajemen nyeri dapat dilakukan dengan menggunakan teknik transcendental meditation dan medical hypnosis yang secara nyata berpengaruh pada penurunan skala nyeri dan sekaligus sebagai terapi non farmakologis untuk membantu mengontrol nyeri. ${ }^{3,4}$

Terapi nonfarmakologis sangat dianjurkan diberikan pada pasien dengan nyeri sendi. Dengan tujuan mengurangi nyeri sendi dan mengendalikan faktor risiko serta penyakit penyerta lainnya. ${ }^{5}$ Manajemen nyeri sendi dapat mengurangi penderitaan dan ketergantungan lansia dalam pemenuhan kebuhan sehari-hari.

Hampir 90\% dari total jumlah lansia yang ada di panti sosial tresna wredha Jambi mengalami nyeri sendi. ${ }^{6}$ Hipnoterapi merupakan salah satu terapi komplementer keperawatan non farmakologis yang dapat direkomendasikan dalam menurunkan skala nyeri. Belum ada penelitian sebelumnya mengenai penggunaan terapi hipnoterapi terhadap nyeri sendi lansia di Jambi. Penelitian ini bertujuan untuk mengetahui pengaruh hipnoterapi terhadap skala nyeri sendi pada lansia di panti sosial Tresna Wredha Jambi.

\section{METODE}

Desain penelitian dengan quasi eksperimen dengan rancangan One group per test-post test atau desain pre and posttest without control, untuk melihat pengaruh hipnoterapi pada sekelompok lansia dengan nyeri sendi tanpa kelompok pembanding.

Populasi dalam penelitian ini adalah seluruh lansia yang menderita nyeri sendi yang berdomisisli di Panti Sosial Tresna Wredha Jambi yang berjumlah 58 lansia.

Jumlah sampel dalam penelitian ini berjumlah 20 lansia, didasarkan pada pendapat Roscoe bahwa untuk penelitian eksperimen sederhana, maka jumlah sampel antara 10-20. ${ }^{7}$

Instrumen penelitian menggunakan skala deskripsi verbal (verbal descriptor scale) untuk skala nyeri. ${ }^{8}$ Prosedur pengumpulan data dimulai dengan melakukan pengkajian terhadap skala nyeri sendi lansia (pre-intervensi), selanjutnya dilakukan informed concern untuk kesediaan menjadi responden. Intervensi dilakukan oleh seorang perawat yang expert dan merupakan praktisi di bidang Hipnoterapi. Pembinaan rasa saling percaya, dan pelaksanaan prosedur hipnoterapi membutuhkan waktu \pm 15-30 menit untuk masing - masing responden. Selanjutnya dilakukan pengkajian dengan mengukur skala nyeri setelah dilakukan hipnoterapi (postintervensi).

\section{HASIL DAN PEMBAHASAN}

Distribusi frekuensi karakteristik responden dapat dilihat pada tabel 1 .

Tabel 1. Distribusi frekuensi responden berdasarkan usia dan jenis kelamin

\begin{tabular}{lcc}
\multicolumn{1}{c}{ Karakteristik } & f & \% \\
\hline USIA (n=20) & 5 & 25.0 \\
60-65 Tahun & 15 & 75.0 \\
\hline 66-70 Tahun & 10 & 50.0 \\
\hline $\begin{array}{l}\text { JENIS KELAMIN (n=20) } \\
\text { Laki-laki }\end{array}$ & 10 & 50.0 \\
\hline Perempuan
\end{tabular}

Hasil analisis bivariat data skala nyeri lansia sebelum dan sesudah dilakukan intervensi hipnoterapi dapat dilihat pada tabel 2 .

Tabel 2. Rerata skala nyeri sebelum dan sesudah intervensi

\begin{tabular}{lcccc}
\hline \multicolumn{1}{c}{ Variabel } & Mean $( \pm$ SD) & Min-Max & $95 \%$ CI & $\begin{array}{c}\boldsymbol{p} \\
\text { value }\end{array}$ \\
\hline $\begin{array}{l}\text { Skala Nyeri } \\
\text { Pre-Test }\end{array}$ & $8,50( \pm 0,946)$ & $7-10$ & & \\
\hline $\begin{array}{l}\text { Skala Nyeri } \\
\text { Post-Test }\end{array}$ & $3,10( \pm 0,718)$ & $2-4$ & $5,944-$ & 0,000 \\
\hline
\end{tabular}

Berdasarkan hasil pengkuran skala nyeri, rata-rata lansia mengalami nyeri berat. Hal ini ditunjukkan dengan skala nyeri 7-10. Rata-rata lansia telah menderita nyeri sendi kronis karena nyeri yang dirasakan lebih dari 6 bulan, Pengalaman sensori dan emosi yang tidak menyenangkan berhubungan dengan kerusakan jaringan actual atau potensial, atau di dekripsikan dengan terminologi dari kerusakan lebih dari enam bulan bahkan selama bertahun-tahun termasuk nyeri kronis..$^{8,9}$

Data pada tabel 2 menunjukkan bahwa rerata skala nyeri lansia setelah dilakukan intervensi berada pada kategori ringan.

Dari hasil pengukuran skala nyeri akhir, didapatkan rata-rata skala nyeri menurun dan nyeri berat menjadi nyeri ringan. Hal ini ditunjukkan dengan skala numeric verbal scale bahwa skala nyeri ringan berada diantara 1-3. Hasil penelitian ini sejalan dengan penelitian Hastuti, nyeri dapat diturunkan sebesar 3,56 setelah dilakukan hipnoterapi. ${ }^{10}$ 
Hipnoterapi merupakan terapi alternatif nonfarmakologi yang dikembangkan saat ini. Cara kerja hipnoterapi dalam pengontrolan nyeri yaitu dengan menstimulasi alam bawah sadar. Pada saat proses stimulasi, otak akan melepaskan neurotransmitter yaitu endorphin sebagai zat kimia yang terdapat di otak. Endorphin memiliki fingsi merubah penerimaan individu terhadap sakit atau gejala fisik lainnya melalui peningkatan mood. ${ }^{11}$

Relaksasi dan persepsi positif dihasilkan oleh kerja otak baik aspek kognitif maupun emosi yang dipengaruhi oleh hipnoterapi. Kondisi psikologis lansia dimanfaatkan untuk merubah persepsi sakit atau nyeri menjadi rasa nyaman melalui Hipnoterapi. ${ }^{12}$

Hipnoterapi merupakan proses merubah kondisi stadium normal ke stadium hipnosis, yaitu dimana kondisi seseorang menjadi lebih sugestif, yang meningkatkan penerimaan terhadap saran- saran yang diubah menjadi nilai baru. Pada kondisi relaksasi, hipnoterapi memfasilitasi individu untuk melakukan relaksasi progresif. Pada keadaan tersebut kebutuhan tubuh akan oksigen menjadi berkurang.

Kondisi relaksasi yang lebih dalam akan dirasakan responden saat memasuki tahap deepening. Hal ini terjadi dikarenakan penurunan kebutuhan tubuh akan oksigen yang diikuti dengan rileksnya otot-otot tubuh, sehingga menimbulkan perasaan tenang dan nyaman. ${ }^{11}$ Pada kondisi ini, gerbang pikiran bawah sadar akan terbuka secara alamiah, sehingga sugesti yang diberikan therapist lebih mudah untuk diterima. Kondisi rileks juga menyebabkan gerbang nyeri yang disebut substansia gelatinosa pada kornu dorsalis medulla spinalis tertutup, impuls nyeri yang ditransmisikan ke otak menjadi berkurang. Hal ini berdampak pada berkurang atau hilangnya perssepsi nyeri.

Hasil penelitian menunjukkan, lama waktu efektif dari intervensi hipnoterapi adalah 5-8 jam. Hal ini sejalan dengan hasil penelitian Hastuti, dan hasil penelitian Yanti dkk, yang melakukan pemberian hipnoterapi pada pasien fraktur ekstremitas di Rumah Sakit Muntilan dan yang diberikan kepada anak usia sekolah pasca pembedahan di RSUP Fatmawati, hanya berlangsung selama $6-8$ jam. ${ }^{10,13}$

Hipnosis yang dilakukan pada pasien lansia dapat pula membantu meningkatkan suasana hati pasien sehingga pasien dapat lebih fokus dalam meningkatkan kesehatannya serta menunjukkan tidak adanya efek samping pada penggunaan terapi hipnoterapi selama bulan. ${ }^{14}$

Hasil penelitian ini masih perlu ditindaklanjuti dengan memberikan pelatihan self hypnosis pada lansia agar dapat menurunkan skala nyeri secara mandiri. Hal ini didukung oleh hasil penelitian Etkins, et., al. ${ }^{5}$ Fokus hipnosis dalam pengobatan nyeri kronis juga sering melibatkan mengajar pasien self-hypnosis atau menyediakan rekaman kaset dari sesi hipnosis yang dapat digunakan untuk mengurangi rasa sakit setiap hari di luar sesi. Hal ini penting karena dengan hypnosis mampu memodulasi sistem kerja otak yang mempersepsikan rasa nyeri. ${ }^{15}$

\section{KESIMPULAN}

Terapi keperawatan komplementer hipnoterapi terbukti dapat menurunkan skala nyeri sendi pada lansia di Panti Sosial Tresna Wredha Jambi. Hipnoterapi dapat dijadikan salah satu alternative pengobatan non farmakologis dalam mengatasi nyeri.

\section{DAFTAR PUSTAKA}

1. Tamsuri A. Konsep dan Penatalaksanaan Nyeri. Jakarta: EGC.2012

2. Potter PA, Perry AG. Fundamental Keperawatan, Ed.7. Terjemahan oleh Diah Nur Fitri, Onny Tampubolon, Farah Diba, Jakarta : Salemba Medika. 2010.

3. Astin JA. Why patients use alternative medicine: Results of a national study. Journal of the American Medical Association 1998;279:15481553.

4. Eisenberg DM, Kessler RC, Foster C, Norlock FE, Calkins DR, Delbanco TL. Unconventional medicine in the United States. Prevalence, costs, and patterns of use. New England Journal of Medicine 1993;328:246-252.

5. Etkins, et., al, 2007.Hypnotherapy for management of Chronic Pain. Int $J$ Clin Exp Hypn. 2007 July ; 55(3): 275-287.

6. Data Survei. Panti Sosial Tresna Wredha Jambi. 2018.

7. Sugiono. Metode Penelitian Kuantitatif, Kualitatif, dan R\&D. Bandung: Alpabeta. 2012.

8. Smeltzer and Bare. Brunner \& Suddart Buku Ajar Keperawatan Medikal Bedah Vol. 3 Edisi 8. Jakarta: EGC. 2002.

9. Well \& Melzack's. Text book of pain, sixth Edition. McMahon. Stephen B. FMedSci, FSB Saunders, an impirint of Elsevier Ltd; 2013

10. Hastuti NP. Pengaruh hipnoterapi terhadap perubahan skala nyeri pasien fraktur ekstremitas di ruang bedah RSU Muntilan. 2011.

11. Rankin-Box, D., \& Williamson, E.M. Complementary medicine: A guide for pharmacists. London: Churchill Livingstone. 2006.

12. Cawthorn, A., \& Mackereth, P. A. Integrative hypnotherapy. Complementary approaches in 
clinical case. London: Churchill Livingstone. 2010.

13. Yanti, I., Rustina, Y., Kuntarti. Hipnoterapi Mengurangi Nyeri Pasca Pembedahan Pada Anak Usia Sekolah. J Fatmawati Hospital. 2013.

14. Ardigo S, Herrmann FR, Moret V, Déramé L, Giannelli S, Gold G, Pautex S. Hypnosis can reduce pain in hospitalized older patients: a randomized controlled study. BMC geriatrics. 2016 Dec 1;16(1):14.

15. Jensen MP, Day MA, Miró J. Neuromodulatory treatments for chronic pain: efficacy and mechanisms. Nature Reviews Neurology. 2014 Mar;10(3):167.

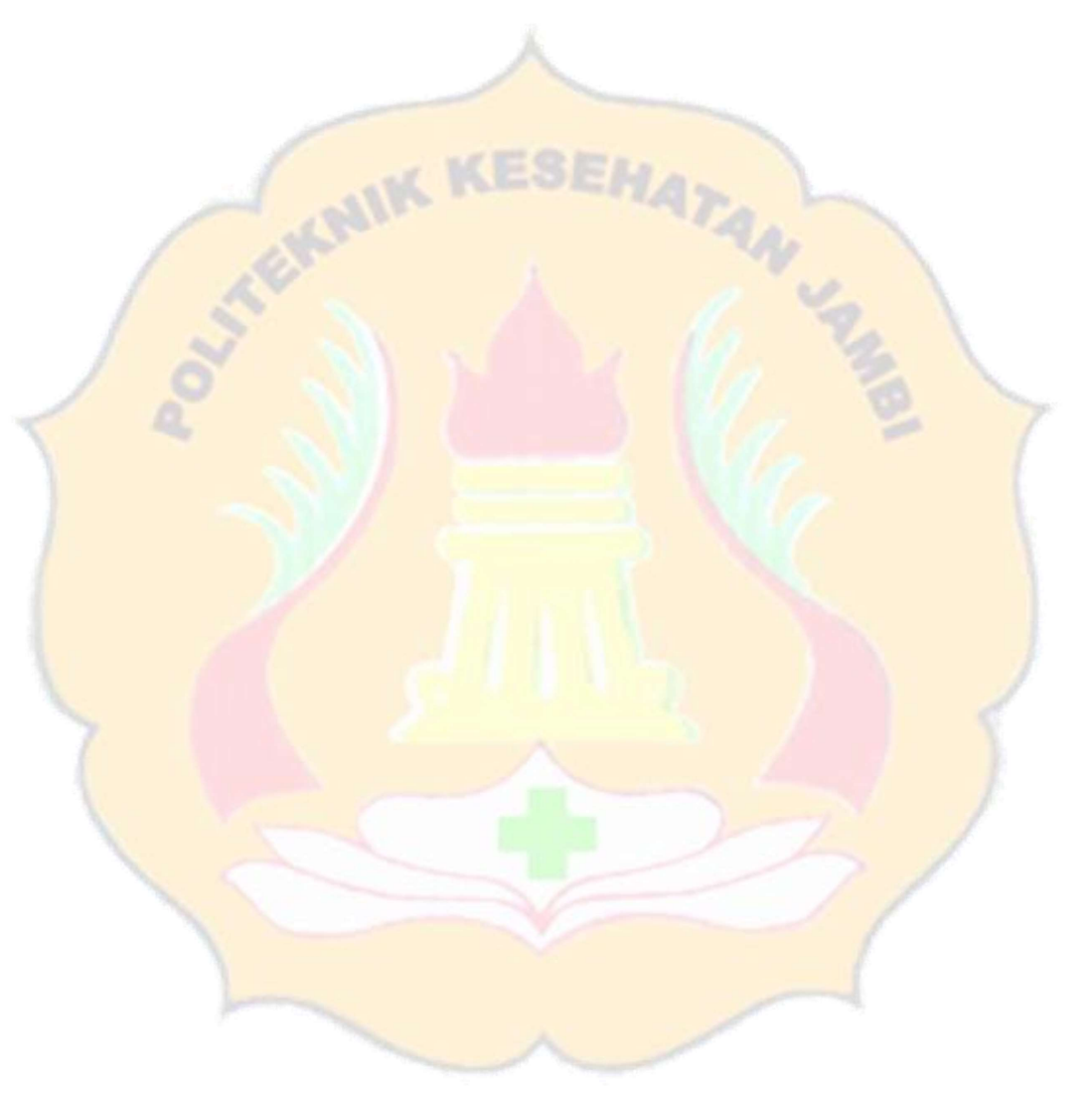

